\title{
Liposome-based Biosensors and Diagnosis Imaging Agents
}

\author{
Nobuhito Hamano* and Yoichi Negishi \\ Department of Drug Delivery and Molecular Biopharmaceutics, School of Pharmacy, \\ Tokyo University of Pharmacy and Life Sciences, 1432-1 Horinouchi, Hachioji, Tokyo 192-0392, Japan
}

(Received August 31, 2021; accepted October 21, 2021; online published February 3, 2022)

Keywords: liposomes, biosensor, point of care, diagnosis, FRET, CT, MRI, ultrasound imaging

The development of biosensors and contrast imaging agents is urgently required to detect and diagnose diseases. Liposomes have been used in various fields as biosensors and imaging agents owing to their biocompatibility, ability to modify the liposomal surface, and encapsulation efficacy for various biologically active agents. In this review, we summarize the current developments and applications of liposome-based biosensors and diagnostic agents, including computed tomography, ultrasound imaging, magnetic resonance imaging, and positron emission tomography. We also discuss future perspectives and challenges associated with the development of liposomal biosensors and imaging agents.

\section{Introduction}

Biosensors are analytical tools composed of biological materials, biologically derived materials, or biomimetics that are used as recognition molecules. Biosensors have been employed in several fields, including the food industry, environment, agriculture, and medicine, owing to their user-friendliness and high sensitivity. ${ }^{(1-3)}$ In vitro, biosensors react with samples such as blood and saliva in a test tube, microtiter plate, or test strip, enabling the detection of contaminants such as viruses. Biosensors generally have four characteristics: selectivity, reproducibility, stability, and sensitivity. ${ }^{(4)}$ In vivo, biosensors function as bioimaging sensors for image diagnosis, making them valuable as imaging agents to enable precise diagnosis in clinical settings. Therefore, biosensor/imaging agents are increasingly important in clinical settings.

Liposomes are artificial vesicles mainly composed of phospholipids and cholesterol. As phospholipids are one of the main cell membrane components, liposomes exhibit excellent biocompatibility, non-toxicity, and a lipid bilayer structure. Accordingly, liposomes have been used as biosensors. Liposomes were first discovered by Dr. Alec Douglas Bangham, a hematologist at the Cambridge Babraham Institute, in the 1960s. ${ }^{(5,6)}$ Originally, liposomes were used as a biological cell membrane model. Then in the early 1970s, it was demonstrated that liposomes could serve as a carrier system for drug delivery. ${ }^{(7,8)}$ Since the introduction of PEGylated liposomes, whose surfaces are coated with polyethylene glycol, by Klibanov et al. in $1990,{ }^{(9)}$ liposomes have been extensively investigated. Moreover, in 1995 Doxil $^{\circledR}$ (PEGylated liposomes containing doxorubicin) was approved by the FDA as the first liposomal

*Corresponding author: e-mail: nhamano@toyaku.ac.jp 
formulation. ${ }^{(10)}$ To date, several functional liposomes have been developed, such as targeting liposomes (e.g., peptide-modified or antibody-modified liposomes) ${ }^{(11,12)}$ and stimuli-responsive liposomes [e.g., pH-responsive, light-activated, and ultrasound (US)-responsive liposomes], ${ }^{(13-16)}$ with over 10 liposomal formulations approved by the FDA. ${ }^{(17)}$

In the present review, we focus on liposomes as biosensors or imaging agents and present recent promising examples of liposomal biosensors and diagnostic imaging agents. In addition, we discuss associated challenges and future perspectives.

\section{Liposomes as Biosensors}

Typically, liposomes are classified into small unilamellar vesicles (SUVs; $20-100 \mathrm{~nm}$ ), large unilamellar vesicles (LUVs; 100-1000 nm), multilamellar vesicles (MUVs; over $500 \mathrm{~nm}$ ), and giant unilamellar vesicles (GUVs; $>1 \mathrm{~mm}$ ) and have a lipid bilayer structure with a thickness of 4-5 nm. ${ }^{18,19)}$ Notably, the liposomal surface can be conjugated with diverse biorecognition molecules [e.g., antibodies, peptides, saccharides, and DNA segments ${ }^{(20-23)}$ ]. In addition, liposomes possess a large cavity and lipid bilayer structure and can encapsulate hydrophilic molecules in the cavity or hydrophobic molecules in the bilayer, including dyes, enzymes, DNA, and organic nanoparticles. ${ }^{(24-27)}$ In addition, liposomes have a high surface area and can amplify signal intensities, ${ }^{(28,29)}$ making them excellent materials for developing biosensors. In this section, we introduce liposomal biosensors developed since the 1990s.

Different types of assays have employed liposomes for biosensing by simply mixing the liposomes with test samples, such as immunoassays [liposome agglutination, liposome immunoaggregation, liposome immunoblotting, immunochromatographic liposome, and liposome-linked immunosorbent assays, ${ }^{(30,31)}$ ]. Liposomes have also been employed as biosensors to detect various analytes (e.g., toxins, pesticides, enzyme, and viruses) (Table 1). Since the mid-1990s, liposomes have been used as biosensors to detect toxins [botulinum toxin, cholera toxin, and Salmonella ${ }^{(24,32,33)}$ ] as well as pesticides [alachlor, carbofuran, and herbicide $^{(34-36)}$. The common features in these liposomal systems were low-molecular-weight encapsulated liposomes (SRB or Tb) and strip assays. In the 2010s, horseradish-peroxidase (HRP)- and polypeptide-encapsulated liposomes have been used to detect enzymes [matrix metalloproteinase (MMP)-9 and phospholipase A2 receptor (PLA2) ${ }^{(25,37)}$; these systems have been used for enzyme-linked immunosorbent assay (ELISA) and colorimetric analysis. As another enzyme detection system, Chowdhury and Park revealed that sphingomyelinase could be detected at a markedly low detection limit $(>0.01 \mathrm{mU} / \mathrm{mL})$ using methylene blue (MB) and electrochemical differential pulse voltammetry (DPV). ${ }^{(38)}$

An excessive production of reactive oxygen species (ROS) has been implicated in the development of various chronic and degenerative diseases, including cancer and respiratory, neurodegenerative, and digestive diseases. ${ }^{(39)}$ Recent evidence has shown that ROS play a key role as messengers in normal cell signal transduction and cell cycling. ROS-detectable liposomal systems have been reported, ${ }^{(27,40)}$ such as a Förster resonance energy transfer (FRET) system for ROS detection. FRET is an effective technique for probing minimal changes occurring at a distance, such as the separation between donor and acceptor fluorophores of less than $10 \mathrm{~nm}$. It 
Table 1

Summary of liposome-based biosensors."

\begin{tabular}{|c|c|c|c|c|c|c|}
\hline Analytes & Type of liposome & $\begin{array}{l}\text { Liposome } \\
\text { composition }\end{array}$ & Marker & $\begin{array}{l}\text { Detection signals } \\
\text { (method) }\end{array}$ & $\begin{array}{l}\text { Detection } \\
\text { limit }\end{array}$ & Ref. \\
\hline \multicolumn{7}{|l|}{ Toxin } \\
\hline $\begin{array}{l}\text { Botulinum } \\
\text { toxin }\end{array}$ & $\begin{array}{c}\text { Ganglioside-modified } \\
\text { liposomes }\end{array}$ & $\begin{array}{c}\text { DPPC, DPPG, } \\
\text { chol, DPPE-ATA }\end{array}$ & SRB & Fluorescence & $15 \mathrm{pg} / \mathrm{mL}$ & 24 \\
\hline Cholera toxin & $\begin{array}{l}\text { Ganglioside-modified } \\
\text { liposomes }\end{array}$ & $\begin{array}{c}\text { DPPC, DPPGchol, } \\
\text { GM1 }\end{array}$ & SRB & Fluorescence & $0.01 \mathrm{pg} / \mathrm{mL}$ & 32 \\
\hline Salmonella & $\begin{array}{l}\text { Antibody-modified } \\
\text { liposomes }\end{array}$ & $\begin{array}{c}\text { DPPC, DPPG, chol, } \\
\text { biotin-X-DHPE, } \\
\text { DPPE }\end{array}$ & SRB & Fluorescence & $100 \mathrm{CFU} / \mathrm{mL}$ & 33 \\
\hline \multicolumn{7}{|l|}{ Pesticides } \\
\hline Alachlor & $\begin{array}{l}\text { Dye-encapsulated } \\
\text { liposomes }\end{array}$ & DPPC, chol & SRB & Fluorescence & $5-10 \mathrm{ng} / \mathrm{mL}$ & 34 \\
\hline Herbicide & $\begin{array}{l}\text { Antigen-sensitized } \\
\text { liposomes }\end{array}$ & $\begin{array}{l}\text { Lecithin, chol, } \\
\text { decetyl Atrazine- } \\
\text { DMPE }\end{array}$ & $\begin{array}{l}\text { Calcein or } \\
\text { SR } 101\end{array}$ & Fluorescence & $0.13 \mathrm{ng} / \mathrm{mL}$ & 36 \\
\hline Carbofuranv & $\begin{array}{l}\text { Tb-encapsulated } \\
\text { liposomes }\end{array}$ & LPC, PE & $\mathrm{Tb}$ & Fluorescence & $\begin{array}{c}0.01-10 \\
\mathrm{ng} / \mathrm{mL}\end{array}$ & 35 \\
\hline \multicolumn{7}{|l|}{ Enzymes } \\
\hline MMP-9 & $\begin{array}{l}\text { Lipopeptide-modified } \\
\text { liposomes }\end{array}$ & POPC, chol & HRP & $\begin{array}{l}\text { Absorbance } \\
\text { (ELISA) }\end{array}$ & N/A & 25 \\
\hline PLA2 & $\begin{array}{l}\text { Polypeptide-loaded } \\
\text { liposomes }\end{array}$ & POPC & Polypeptide & Colorimetric & $\begin{array}{c}0.07-7 \\
\mathrm{pmol} / \mathrm{mL}\end{array}$ & 37 \\
\hline $\begin{array}{l}\text { Sphingomye } \\
\text { linase }\end{array}$ & Bare liposomes & Sphingomyelin, chol & MB & $\begin{array}{l}\text { Differential pulse } \\
\text { voltammetric } \\
\text { (electrochemical } \\
\text { DPV process) }\end{array}$ & $\begin{array}{r}0.1-10 \\
\mathrm{mU} / \mathrm{mL}\end{array}$ & 38 \\
\hline \multirow[t]{3}{*}{ ROS } & Boronate-modified & DOPE-based lipids & ANTS/DPX & $\begin{array}{l}\text { Fluorescence } \\
\text { (FRET) }\end{array}$ & N/A & 40 \\
\hline & liposomes & DPPC, DOPE, PA & & & & \\
\hline & $\begin{array}{c}\text { Chlorophyll } \\
\text { a-embedded liposomes }\end{array}$ & $\begin{array}{c}\text { DPPC, chol, } \\
\text { DSPE-PEG2000 }\end{array}$ & $\begin{array}{l}\text { UCNPs/ } \\
\text { AuNPs }\end{array}$ & $\begin{array}{c}\text { Fluorescence } \\
\text { (FRET) }\end{array}$ & $\begin{array}{c}25-50 \mathrm{mM} \\
\left(\mathrm{H}_{2} \mathrm{O}_{2}\right)\end{array}$ & 27 \\
\hline \multicolumn{7}{|l|}{ Viruses } \\
\hline Dengue RNA & $\begin{array}{l}\text { DNA probe-modified } \\
\text { liposomes }\end{array}$ & $\begin{array}{l}\text { DPPC, DPPG, } \\
\text { chol, DPPE }\end{array}$ & DNAprobes & $\begin{array}{l}\text { Electrochemi- } \\
\text { luminescence }\end{array}$ & $10 \mathrm{pfu} / \mathrm{mL}$ & 23 \\
\hline $\begin{array}{l}\text { Chikungunya } \\
\text { virus E1 } \\
\text { protein }\end{array}$ & $\begin{array}{l}\text { Antibody-modified } \\
\text { liposomes }\end{array}$ & $\begin{array}{l}\text { DOPC, DOPG, } \\
\text { DSPE-PEG2000 }\end{array}$ & $\mathrm{MB} / \mathrm{QDs}$ & $\begin{array}{l}\text { Electrochemical } \\
\text { and fluorescence }\end{array}$ & $\begin{array}{c}0.03-0.56 \\
\mathrm{pg} / \mathrm{ml}\end{array}$ & 44 \\
\hline $\begin{array}{l}\text { SARS-CoV-2 } \\
\text { RNA }\end{array}$ & Bare liposomes & DMPC, chol & CRISPR-FDS & Fluorescence & N/A & 26 \\
\hline
\end{tabular}

*Abbreviations: chol = cholesterol; $\mathrm{SRB}=$ sulforhodamine $\mathrm{B} ; \mathrm{PC}=$ phosphatidylcholine; $\mathrm{PE}=$ phosphatidylethanolamine; $\mathrm{PA}=1-\alpha$-phosphatidic acid sodium salt from chicken eggs; ANTS $=8$-aminonaphthalene-1,3,6-trisulfonic acid; $\mathrm{DPX}=$ p-xylene-bis-pyridinium bromide; $\mathrm{UCNPs}=$ upconverting nanoparticles; AuNPs $=$ gold nanoparticles; $\mathrm{PG}=$ phosphatidylglycerol; $\mathrm{MB}=$ methylene blue; $\mathrm{QDs}=$ quantum dots.

is also a sensitive tool for detecting molecular binding and changes in protein conformation, as well as for chemical and biological analyses. ${ }^{(41-43)}$ Liposomes have a bilayer structure and a thickness of approximately $5 \mathrm{~nm}$; accordingly, FRET is highly suitable for biosensor applications. Moreover, a liposomal nanoplatform reported by Wan et al. encapsulated upconversion nanoparticle (UCNP)-gold nanoparticle (AuNP) nanocomplexes, which could measure ROS concentrations via FRET imaging while also scavenging excessive ROS. ${ }^{(27)}$ 
Viral diseases are widespread infections caused by viruses, a type of microorganism. If community risk or transmission levels are substantial or high, monitoring or screening tests are especially important, as in the case of severe acute respiratory syndrome coronavirus 2 (SARSCoV-2). Virus-detectable liposomal systems have been reported. ${ }^{(23,44)}$ In 2021, SARS-CoV-2 RNA was detected in human clinical samples using liposomal systems. ${ }^{(26)}$ In general, quantitative reverse-transcriptase polymerase chain reaction (qRT-PCR) has been the gold standard for analyzing respiratory samples to diagnose coronavirus disease 2019 (COVID-19). ${ }^{(45)}$ However, one critical limitation is that the SARS-CoV-2 RNA level in the upper respiratory tract rapidly decreases after infection. ${ }^{(46)}$ In addition, the sensitivity for SARS-CoV-2 RNA in plasma is insufficient owing to the dilution and degradation of viral RNA released into the circulation. ${ }^{(47)}$ Therefore, Ning et al. collected plasma samples from patients with COVID-19 and captured extracellular vesicles (exosomes) that contained viral RNA. They developed reverse transcriptase (RT) and recombinant polymerase amplification, clustered regularly interspaced short palindromic repeat (CRISPR) 12a-encapsulated liposomes, and established SARS-CoV-2 RNApositive detection systems by mixing liposomes and extracellular vesicles. Interestingly, the extracellular plasma vesicles collected from six patients with negative nasal RT-PCR results strongly reacted in the assay system. ${ }^{(26)}$

Accordingly, liposomes have been widely adopted as biosensors for various analytes. For biosensor applications, virus detection systems, such as those developed by Ning et al., are crucial from the perspective of point-of-care testing (POCT). ${ }^{(26,48)}$ POCT enables rapid testing, thus allowing healthcare professionals to make quick decisions and take appropriate treatment measures; however, some challenges persist. In the systems of Ning et al., liposome-encapsulated RNA, Cas12a, and enzymes are associated with liposomal stability. Accordingly, to overcome this issue, the development of novel liposome-based technologies is crucial. For instance, it was recently reported that the combination of microfluidic technology and $\mathrm{pH}$-responsive lipids could generate stable RNA-encapsulated lipid nanoparticles. ${ }^{(49-51)}$ Thus, this pharmaceutical technology could be valuable for developing novel biosensors.

\section{Liposomes as Imaging Agents for Diagnosis}

Medical imaging techniques such as computed tomography (CT), magnetic resonance imaging (MRI), US, and positron emission tomography (PET) play an important role in medicine by facilitating disease diagnosis and treatment. Contrast imaging agents, such as gadolinium (III) (Gd) and iodine-based contrast media, are often employed to enhance images or the disease detection ratio. As previously mentioned, liposomes can encapsulate drugs, and the liposomal size is $<200 \mathrm{~nm}$. Typically, the width of the tight junction regions between blood endothelial cells ranges from 12 to $20 \mathrm{~nm} .{ }^{(52)}$ However, in some vasculature abnormalities (e.g., tumor vascular or inflammation area), the vascular endothelium is disjointed, irregular, and allows the penetration of nanocarriers such as liposomes; this phenomenon is called the enhanced permeability and retention effect. ${ }^{(53)}$ Therefore, liposomes can be valuable as carriers for diagnostic imaging agents. In this section, we introduce liposomal diagnostic imaging agents used in CT, MRI, US, and PET (Table 2). 
Table 2

Summary of liposome-based imaging agents.*

\begin{tabular}{|c|c|c|c|c|c|c|}
\hline $\begin{array}{l}\text { Imaging } \\
\text { modality }\end{array}$ & Type of probe & Type of liposome & Composition & Size & $\begin{array}{c}\text { Experimental } \\
\text { model }\end{array}$ & Ref. \\
\hline \multirow{3}{*}{$\mathrm{CT}$} & Iomeprol & $\begin{array}{l}\text { Tf-modified } \\
\text { liposomes }\end{array}$ & $\begin{array}{c}\text { DSPC, chol, } \\
\text { DSPE-PEG2000 }\end{array}$ & $<150 \mathrm{~nm}$ & Rat glioma model & 85 \\
\hline & Iodixanol & PEG liposomes & $\begin{array}{c}\text { DPPC, chol, DSPE- } \\
\text { PEG2000 }\end{array}$ & $<140 \mathrm{~nm}$ & $\begin{array}{c}\text { Primary or } \\
\text { metastatic tumor } \\
\text { model }\end{array}$ & 57 \\
\hline & Gold nanostars & $\begin{array}{l}\text { FA-modified } \\
\text { liposomes }\end{array}$ & $\begin{array}{l}\text { DSPC, DPPC, DSPE- } \\
\text { PEG2000 silica, Dox }\end{array}$ & $200 \mathrm{~nm}$ & $\begin{array}{l}\text { HeLa xenograft } \\
\text { model }\end{array}$ & 58 \\
\hline \multirow{3}{*}{ MRI } & Gd & $\begin{array}{l}\text { a4b1-targeted } \\
\text { liposomes }\end{array}$ & $\begin{array}{c}\text { TIT0567, DPPC, chol, } \\
\text { BSA-DTPA-Gd }\end{array}$ & $120-250 \mathrm{~nm}$ & $\begin{array}{c}\text { Atherosclerotic } \\
\text { plaque model }\end{array}$ & 63 \\
\hline & Gd & $\begin{array}{c}\text { EGFR-targeted } \\
\text { liposomes }\end{array}$ & $\begin{array}{l}\text { CFL, porphyrin, DSPE- } \\
\text { DOTA, DSPE-PEG- } \\
\text { cetuximab }\end{array}$ & $90 \mathrm{~nm}$ & $\begin{array}{l}\text { Mouse colorectal } \\
\text { tumor model }\end{array}$ & 65 \\
\hline & Magnevist & PEG liposomes & $\begin{array}{c}\text { DPPC, MPPC DSPE- } \\
\text { PEG2000 }\end{array}$ & $170 \mathrm{~nm}$ & $\begin{array}{l}\text { Pancreatic cancer } \\
\text { PDX model }\end{array}$ & 64 \\
\hline \multirow{4}{*}{ US } & Perfluoropropane & $\begin{array}{l}\text { Antibody-modified } \\
\text { nanobubbles }\end{array}$ & DSPC, DSPE-PEG2000 & $500-700 \mathrm{~nm}$ & $\begin{array}{c}\text { SKOV3 xenograft } \\
\text { model }\end{array}$ & 20 \\
\hline & Perfluoropropane & $\begin{array}{c}\text { Annexin } \\
\text { V-modified } \\
\text { nanobubbles }\end{array}$ & $\begin{array}{c}\text { DPPC, chol, } \\
\text { DSPE-PEG2000 }\end{array}$ & $635 \mathrm{~nm}$ & $\begin{array}{l}\text { MDA-MB-231 } \\
\text { xenograft model }\end{array}$ & 72 \\
\hline & Perfluoropropane & $\begin{array}{c}\text { Peptide-modified } \\
\text { nanobubbles }\end{array}$ & DSPC, DSPE-PEG2000 & $420 \mathrm{~nm}$ & $\begin{array}{l}\text { Mouse colon } 26 \\
\text { tumor model }\end{array}$ & 73 \\
\hline & Perfluoropropane & $\begin{array}{l}\text { FA-modified } \\
\text { nanobubbles }\end{array}$ & $\begin{array}{c}\text { DSPC, DSPE-PEG2000- } \\
\text { ICG, DSPE-PEG2000- } \\
\text { FA, RV }\end{array}$ & $1290 \mathrm{~nm}$ & $\begin{array}{l}\text { HepG2 xenograft } \\
\text { model }\end{array}$ & 74 \\
\hline \multirow[b]{2}{*}{ PET } & ${ }^{52} \mathrm{Mn} /{ }^{64} \mathrm{Cu}$ & PEG liposomes & $\begin{array}{c}\text { HSPC, chol, } \\
\text { DSPE-PEG2000 }\end{array}$ & around $100 \mathrm{~nm}$ & $\begin{array}{c}\text { Mouse colon26 } \\
\text { tumor model }\end{array}$ & 77 \\
\hline & ${ }^{64} \mathrm{Cu}$ & $\begin{array}{l}\text { MM-DX-929 } \\
\text { liposomes }\end{array}$ & $\begin{array}{l}\text { DSPC, chol, DSPE- } \\
\text { PEG2000, TEA-SOS, } \\
{ }^{64} \mathrm{Cu}: 4-D E A P-A T S C\end{array}$ & $<100 \mathrm{~nm}$ & $\begin{array}{l}\text { HT29 xenograft } \\
\text { model }\end{array}$ & 78 \\
\hline
\end{tabular}

*Abbreviations: $\mathrm{Tf}=$ transferrin; FA $=$ folic acid; Dox $=$ doxorubicin; $\mathrm{Gd}=$ gadolinium; TIT0567 = $\alpha 4 \beta 1$ integrin antagonist; ICG = indocyanine green; RV = resveratrol; TEA-SOS = triethylammonium sucrose octasulfate.

$\mathrm{CT}$ is a non-invasive radiological imaging technique that uses $\mathrm{X}$-rays to produce $3 \mathrm{D}$ tomographic (cross-sectional) tissue images. CT can image the whole body, including bone and lungs, although it is difficult to obtain high-quality images that can identify the interface between two different tissues, such as a tumor in an organ or a soft tissue in body fluids. ${ }^{54,55)}$ Contrast CT, which employs a contrast agent injection, affords better results and enhances the contrast between target and normal tissues. The contrast agent is often iodine, which can increase the CT contrast of blood vessels; however, iodinated contrast media can potentially induce acute kidney injury. ${ }^{(56)}$ Iodine can be easily encapsulated in liposomes. Therefore, liposomal iodine is an attractive CT contrast agent as its persistence in the blood pool eliminates the need for precisely timing the contrast injection during scanning. Furthermore, non-renal clearance via the reticuloendothelial system can decrease nephrotoxicity. Ghaghada et al. reported that long-circulating liposomal iodine contrast agents enabled the prolonged visualization of small and large tumors in companion dogs with naturally occurring cancer. ${ }^{(57)}$ In addition, metal-based agents, such as gold nanoparticles, can be employed as contrast imaging 
agents. For example, An et al. developed gold-nanostar-encapsulated liposomes and presented CT tumor images. ${ }^{(58)}$ Moreover, this platform showed controlled drug release and cancer chemotherapeutic effects by using a combination of doxorubicin and a near-infrared laser.

MRI is a form of nuclear magnetic resonance, which images hydrogen atoms in biological tissues, mainly water and fat in the body. Accordingly, it does not require contrast agents to image anatomical structures or blood flow. However, MRI has limitations such as cost, long imaging times, motion artifacts, and potential foreign body/implant artifacts. MRI contrast agents significantly help detect and differentiate healthy tissues. ${ }^{(59,60)}$ Gadolinium (Gd) is currently the most common MRI contrast agent. Given the toxicity of free Gd ions, clinical contrast agents are available in the form of Gd chelates (Gd III complexes). Nevertheless, some concerns regarding nephrogenic systemic fibrosis and brain deposition of Gd persist. ${ }^{(61)}$ In addition, MRI has a high resolution but low sensitivity; ${ }^{(62)}$ therefore, it often requires numerous imaging agents. On the basis of these findings, liposomal $\mathrm{Gd}$, which can be employed to image atherosclerotic plaques or tumors with high resolution, has been developed. ${ }^{(63-65)}$ In particular, MRI signals could be detected $48 \mathrm{~h}$ post-injection of targeted liposomal Gd [epidermal growth factor receptor (EGFR)-targeted liposomes], as developed by Li et al.; this effect was not observed with control liposomes. ${ }^{(65)}$ Thus, liposomal Gd formulations can increase the blood circulation time and tissue accumulation by targeting liposomes, which partially resolves the problem of low sensitivity. Also, Gd has been incorporated or encapsulated in almost all liposomal Gd formulations. ${ }^{(63-66)}$ Thus, although there is still the possibility of Gd leakage, liposomal Gd formulations are well tolerated with no safety issues. ${ }^{(63,66)}$

US imaging is one of the most widely used medical diagnostic imaging modalities owing to its portability, noninvasiveness, high spatial resolution, low cost, and real-time imaging properties. Similarly to CT and MRI, US imaging can also image tissues without contrast agents; however, to enhance and improve the resolution and sensitivity of imaging, contrast agents called microbubbles are often employed. Currently available commercial US contrast agents (e.g., Sonazoid and SonoVue) are composed of lipids with sizes ranging between 1 and $8 \mu \mathrm{m} .{ }^{(67-69)}$ However, microbubbles have a relatively short circulation lifetime and low stability owing to their large size. ${ }^{(70,71)}$ Accordingly, nanosized liposome-based US contrast agents have been developed. Moreover, targeting nanobubbles have been formulated for precise imaging. Targeting nanobubbles can be modified by peptides, antibodies, folate, or annexin $\mathrm{V}$ to target tumor tissues, including apoptosis areas and tumor vessels. ${ }^{(20,72-74)}$ Moreover, targeting nanobubbles can allow a prolonged imaging time and robust signals. In addition, photoacoustic (PA) imaging, a hybrid optical and US imaging technique, has attracted attention owing to its advantages such as high contrast and excellent spatial resolution because of the optical imaging properties and deeper tissue penetration afforded by US imaging. Zheng's group developed porphyrin and lipid-based microbubbles (MBs), ${ }^{(75,76)}$ which can control the size (small porphyrin MBs, $2 \mu \mathrm{m}$; large porphyrin MBs, $6 \mu \mathrm{m}$ ) and obtain both US and PA signals, resulting in US and PA bimodal imaging. ${ }^{(76)}$

PET, a powerful and widely employed nuclear medicine technology, allows high tissue penetration, high sensitivity, and real-time quantitative imaging analysis after the injection of positron-emitting radionuclides, such as ${ }^{18} \mathrm{~F},{ }^{64} \mathrm{Cu}$, and ${ }^{89} \mathrm{Zr}$. However, PET has limitations such 
as high cost, rapid attenuation of radionuclides, and radioactive exposure. Therefore, liposomebased PET imaging can overcome some limitations. One potential advantage of liposome-based PET imaging is the increased blood circulation time of radionuclides. Jensen et al. reported that the plasma half-life of ${ }^{64} \mathrm{Cu}$-encapsulated liposomes is longer than that of ${ }^{64} \mathrm{Cu}$ alone $(20.3 \mathrm{~h}$ vs 12.7 h). ${ }^{(77)}$ Blocker et al. assessed the therapeutic efficacy of bevacizumab, an anti-vascular endothelial growth factor drug, using ${ }^{64} \mathrm{Cu}$-labeled liposomes. They observed that imaging with ${ }^{64} \mathrm{Cu}$-labeled liposomes might confer a therapeutic effect on monitoring or enable the prediction of the therapeutic effect. ${ }^{(78)}$

In this manner, using liposomal diagnostic imaging agents, various imaging techniques and combinations are available, such as multimodal imaging and useful tools; however, PEGylated liposomal formulations induce anti-PEG IgG antibodies, resulting in the accelerated blood clearance $(\mathrm{ABC})$ phenomenon. ${ }^{(79-82)}$ The induction of this phenomenon might greatly inhibit the use of liposomal imaging agents. ${ }^{(83)}$ Therefore, to optimize the efficacy of liposomal imaging agents, it is necessary to consider the lipid dose and time interval to minimize the $\mathrm{ABC}$ phenomenon. ${ }^{(84)}$

\section{Conclusions and Future Perspectives}

Liposomes have been used in various fields as biosensors and imaging agents owing to their biocompatibility, as well as their ability to modify the liposomal surface and encapsulate various biologically active agents. Recently, the concept of "theranostics" has been widely used in nanomedicine. ${ }^{(86)}$ This word is a combination of two words, therapeutic and diagnostic, allowing the combination of diagnosis and treatment. Theranostic systems are currently in the preliminary stages; however, some reports indicate their strong potential for tumor treatment. The carriers of theranostic systems include micelles, lipid nanoparticles, and liposomes. ${ }^{(87-90)}$ One of the advantages of liposomes is that many liposomal formulations have already been approved by the FDA. ${ }^{(17)}$ Moreover, because theranostic liposomal formulations containing imaging agents can be used to monitor the drug or carrier, they may be suitable for dose optimization in preclinical studies. This would allow the results to be used to assess efficacy in preclinical studies or clinical trials, facilitating their clinical use. To launch novel theranostic liposomal formulations, the design of future theranostic systems will need to integrate both formulation properties (e.g., biodistribution) and imaging properties.

\section{References}

1 H. Turasan and J. Kokini: Annu. Rev. Food Sci. Technol. 12 (2021) 539. https://doi.org/10.1146/annurevfood-062520-082307

2 Y. Lu, Q. Yang, and J. Wu: TrAC Trends Anal. Chem. 128 (2020) 115914. https://doi.org/10.1016/j. trac. 2020.115914

3 A. Haleem, M. Javaid, R. P. Singh, R. Suman, and S. Rab: Sens. Int. 2 (2021) 100100. https://doi.org/10.1016/j. sint1.2021.100100

4 N. Bhalla, P. Jolly, N. Formisano, and P. Estrela: Essays Biochem. 60 (2016) 1. https://doi.org/10.1042/ ebc20150001

5 A. D. Bangham and R. W. Horne: Nature 196 (1962) 952. https://doi.org/10.1038/196952a0

6 A. D. Bangham and R. W. Horne: J. Mol. Biol. 8 (1964) 660. https://doi.org/10.1016/s0022-2836(64)80115-7 
7 G. Gregoriadis: N. Engl. J. Med. 295 (1976) 704. https://doi.org/10.1056/nejm197609232951305

8 G. Gregoriadis: N. Engl. J. Med. 295 (1976) 765. https://doi.org/10.1056/nejm197609302951406

9 A. L. Klibanov, K. Maruyama, V. P. Torchilin, and L. Huang: FEBS Lett. 268 (1990) 235. https://doi. org/10.1016/0014-5793(90)81016-h

10 Y. Barenholz: J. Control. Release 160 (2012) 117. https://doi.org/10.1016/j.jconrel.2012.03.020

11 N. Oku, T. Asai, K. Watanabe, K. Kuromi, M. Nagatsuka, K. Kurohane, H. Kikkawa, K. Ogino, M. Tanaka, D. Ishikawa, H. Tsukada, M. Momose, J. Nakayama, and T. Taki: Oncogene 21 (2002) 2662. https://doi. org/10.1038/sj.onc. 1205347

12 D. L. Iden and T. M. Allen: Biochim. Biophys. Acta 1513 (2001) 207. https://doi.org/10.1016/s00052736(01)00357-1

13 J. J. Sudimack, W. Guo, W. Tjarks, and R. J. Lee: Biochim. Biophys. Acta 1564 (2002) 31. https://doi. org/10.1016/s0005-2736(02)00399-1

14 A. Mueller, B. Bondurant, and D. F. O'Brien: Macromolecules 33 (2000) 4799. https://doi.org/10.1021/ ma0000551

15 R. Suzuki, T. Takizawa, Y. Negishi, N. Utoguchi, and K. Maruyama: Int. J. Pharm. 354 (2008) 49. https://doi. org/10.1016/j.ijpharm.2007.10.034

16 Y. Negishi, Y. Endo, T. Fukuyama, R. Suzuki, T. Takizawa, D. Omata, K. Maruyama, and Y. Aramaki: J. Control. Release 132 (2008) 124. https://doi.org/10.1016/j.jconrel.2008.08.019

17 E. Beltrán-Gracia, A. López-Camacho, I. Higuera-Ciapara, J. B. Velázquez-Fernández, and A. A. VallejoCardona: Cancer Nanotechnol. 10 (2019) 11. https://doi.org/10.1186/s12645-019-0055-y

18 R. Nordström, L. Zhu, J. Härmark, Y. Levi-Kalisman, E. Koren, Y. Barenholz, G. Levinton, and D. Shamrakov: Pharmaceutics 13 (2021) 1. https://doi.10.3390/pharmaceutics13010123

19 J. Kotouček, F. Hubatka, J. Mašek, P. Kulich, K. Velínská, J. Bezděková, M. Fojtíková, E. Bartheldyová, A. Tomečková, J. Stráská, D. Hrebík, S. Macaulay, I. Kratochvílová, M. Raška, and J. Turánek: Sci. Rep. 10 (2020) 5595. https://doi.org/10.1038/s41598-020-62500-2

20 N. Hamano, S. Kamoshida, Y. Kikkawa, Y. Yano, T. Kobayashi, Y. Endo-Takahashi, R. Suzuki, K. Maruyama, Y. Ito, M. Nomizu, and Y. Negishi: Pharmaceutics 11 (2019) 283. https://doi.org/10.3390/pharmaceutics11060283

21 N. Hamano, Y. Negishi, D. Omata, Y. Takahashi, M. Manandhar, R. Suzuki, K. Maruyama, M. Nomizu, and Y. Aramaki: Mol. Pharm. 10 (2013) 774. https://doi.org/10.1021/mp300463h

22 Y. Ma, H. Zhang, V. Gruzdys, and X.-L. Sun: Langmuir 27 (2011) 13097. https://doi.org/10.1021/la2032434

23 A. J. Baeumner, N. A. Schlesinger, N. S. Slutzki, J. Romano, E. M. Lee, and R. A. Montagna: Anal. Chem. 74 (2002) 1442. https://doi.org/10.1021/ac015675e

24 S. Ahn-Yoon, T. R. DeCory, and R. A. Durst: Anal. Bioanal. Chem. 378 (2004) 68. https://doi.org/10.1007/ S00216-003-2365-4

25 J. Banerjee, A. J. Hanson, E. K. Nyren-Erickson, B. Ganguli, A. Wagh, W. W. Muhonen, B. Law, J. B. Shabb, D. K. Srivastava, and S. Mallik: Chem. Commun. 46 (2010) 3209. https://doi.org/10.1039/b926554f

26 B. Ning, Z. Huang, B. M. Youngquist, J. W. Scott, A. Niu, C. M. Bojanowski, K. J. Zwezdaryk, N. S. Saba, J. Fan, X. M. Yin, J. Cao, C. J. Lyon, C. Z. Li, C. J. Roy, and T. Y. Hu: Nat. Nanotechnol. 16 (2021) 1039. https:// doi.org/10.1038/s41565-021-00939-8

27 W. L. Wan, B. Tian, Y. J. Lin, C. Korupalli, M. Y. Lu, Q. Cui, D. Wan, Y. Chang, and H. W. Sung: Nat. Commun. 11 (2020) 534. https://doi.org/10.1038/s41467-020-14413-X

28 H. A. H. Rongen, A. Bult, and W. P. Van Bennekom: J. Immunol. Methods 204 (1997) 105. https://doi. org/10.1016/s0022-1759(97)00041-0

29 K. A. Edwards and A. J. Baeumner: Talanta 68 (2006) 1421. https://doi.org/10.1016/j.talanta.2005.08.044

30 J. Sforzi, L. Palagi, and S. Aime: Biology (Basel) 9 (2020) 202. https://doi.org/10.3390/biology 9080202

31 R. Hu, K. Sou, and S. Takeoka: Sci. Rep. 10 (2020) 18086. https://doi.org/10.1038/s41598-020-75011-x

32 S. Ahn and R. A. Durst: Anal. Bioanal. Chem. 391 (2008) 473. https://doi.org/10.1007/s00216-007-1551-1

33 J. A. Ho, S. C. Zeng, W. H. Tseng, Y. J. Lin, and C. H. Chen: Anal. Bioanal. Chem. 391 (2008) 479. https://doi. org/10.1007/s00216-008-1875-5

34 S. T. A. Siebert, S. G. Reeves, and R. A. Durst: Anal. Chim. Acta 282 (1993) 297. https://doi.org/10.1016/00032670(93)80214-6

35 M. A. Bacigalupo, G. Meroni, and R. Longhi: Talanta 69 (2006) 1106. https://doi.org/10.1016/j. talanta.2005.12.018

36 O. D. Hendrickson, S. N. Skopinskaya, S. P. Yarkov, A. V. Zherdev, and B. B. Dzantiev: J. Immunoassay Immunochem. 25 (2004) 279. https://doi.org/10.1081/ias-200028084

37 D. Aili, M. Mager, D. Roche, and M. M. Stevens: Nano Lett. 11 (2010) 1401. https://doi.org/10.1021/n11024062

38 A. D. Chowdhury and E. Y. Park: Sens. Actuators, B 301 (2019) 127153. https://doi.org/10.1016/j. snb.2019.127153 
39 Z. Liu, Z. Ren, J. Zhang, C.-C. Chuang, E. Kandaswamy, T. Zhou, and L. Zuo: Front. Physiol. 9 (2018) 477. https://doi.org/10.3389/fphys.2018.00477

40 J. Lou and M. D. Best: Bioconjug. Chem. 31 (2020) 2220. https://doi.org/10.1021/acs.bioconjchem.0c00397

41 X. Huang, M. Swierczewska, K. Y. Choi, L. Zhu, A. Bhirde, J. Park, K. Kim, J. Xie, G. Niu, K. C. Lee, S. Lee, and X. Chen: Angew. Chemie Int. Ed. 51 (2012) 1625. https://doi.org/10.1002/anie.201107795

42 K. Zhou, H. Liu, S. Zhang, X. Huang, Y. Wang, G. Huang, B. D. Sumer, and J. Gao: J. Am. Chem. Soc. 134 (2012) 7803. https://doi.org/10.1021/ja300176w

43 N. Hamano, M. Murata, T. Kawano, J. S. Piao, S. Narahara, R. Nakata, T. Akahoshi, T. Ikeda, and M. Hashizume: ACS Appl. Mater. Interfaces 8 (2016) 5114. https://doi.org/10.1021/acsami.5b11902

44 F. Nasrin, A. D. Chowdhury, A. B. Ganganboina, O. J. Achadu, F. Hossain, M. Yamazaki, and E. Y. Park: Mikrochim. Acta 187 (2020) https://doi.org/10.1007/s00604-020-04656-2

45 B. Udugama, P. Kadhiresan, H. N. Kozlowski, A. Malekjahani, M. Osborne, V. Y. C. Li, H. Chen, S. Mubareka, J. B. Gubbay, and W. C. W. Chan: ACS Nano 14 (2020) 3822. https://doi.org/10.1021/acsnano.0c02624

46 Y. Liu, L. M. Yan, L. Wan, T. X. Xiang, A. Le, J. M. Liu, M. Peiris, L. L. M. Poon, and W. Zhang: Lancet Infect. Dis. 20 (2020) 656. https://doi.org/10.1016/s1473-3099(20)30232-2

47 M. Azghandi and M. A. Kerachian: J. Transl. Med. 18 (2020) 412. https://doi.org/10.1186/s12967-020-02589-1

48 P. B. Luppa: J. Lab. Med. 44 (2020) 59. https://doi.org/10.1515/labmed-2020-0020

49 N. M. Belliveau, J. Huft, P. J. Lin, S. Chen, A. K. Leung, T. J. Leaver, A. W. Wild, J. B. Lee, R. J. Taylor, Y. K. Tam, C. L. Hansen, and P. R. Cullis: Mol. Ther. Nucleic Acids 1 (2012) e37. https://doi.org/10.1038/ mtna.2012.28

50 A. Akinc, M. A. Maier, M. Manoharan, K. Fitzgerald, M. Jayaraman, S. Barros, S. Ansell, X. Du, M. J. Hope, T. D. Madden, B. L. Mui, S. C. Semple, Y. K. Tam, M. Ciufolini, D. Witzigmann, J. A. Kulkarni, R. van der Meel, and P. R. Cullis: Nat. Nanotechnol. 14 (2019) 1084. https://doi.org/10.1038/s41565-019-0591-y

51 Y. N. Lamb: Drugs 81 (2021) 495. https://doi.org/10.1007/s40265-021-01480-7

52 F. Antohe, L. Lin, G. Y. Kao, M. J. Poznansky, and T. M. Allen: J. Liposome Res. 14 (2004) 1. https://doi. org/10.1081/lpr-120039660

53 Y. Matsumura and H. Maeda: Cancer Res. 46 (1986) 6387. https://doi.org/10.1021/bc100070g

54 H. Lusic and M. W. Grinstaff: Chem. Rev. 113 (2012) 1641. https://doi.org/10.1021/CR200358S

55 K. Chatterjee, S. Sarkar, K. Jagajjanani Rao, and S. Paria: Adv. Colloid Interface Sci. 209 (2014) 8. https://doi. org/10.1016/j.cis.2013.12.008

56 A. L. Faucon, G. Bobrie, and O. Clément: Eur. J. Radiol. 116 (2019) 231. https://doi.org/10.1016/j. ejrad.2019.03.008

57 K. B. Ghaghada, A. F. Sato, Z. A. Starosolski, J. Vail, and D. M. Berg: PLoS One (2016) e0152718. https://doi. org/10.1371/journal.pone.0152718

58 J. An, X. Q. Yang, K. Cheng, X. L. Song, L. Zhang, C. Li, X. S. Zhang, Y. Xuan, Y. Y. Song, B. Y. Fang, X. L. Hou, Y. D. Zhao, and B. Liu: ACS Appl. Mater. Interfaces 9 (2017) 41748. https://doi.org/10.1021/ acsami.7b15296

59 M. R. Bashir: Magn. Reason. Imaging Clin. N. Am. 22 (2014) 283. https://doi.org/10.1016/j.mric.2014.04.002

60 H. Donato, M. França, I. Candelária, and F. Caseiro-Alves: Eur. J. Radiol. 93 (2017) 30. https://doi.org/10.1016/j. ejrad.2017.05.028

61 C. Do, J. DeAguero, A. Brearley, X. Trejo, T. Howard, G. P. Escobar, and B. Wagner: Kidney360 1 (2020) 561. https://doi.org/10.34067/kid.0000272019

62 F. A. Gallagher: Clin. Radiol. 65 (2010) 557. https://doi.org/10.1016/j.crad.2010.04.006

63 D. G. Woodside, E. A. Tanifum, K. B. Ghaghada, R. J. Biediger, A. R. Caivano, Z. A. Starosolski, S. Khounlo, S. Bhayana, S. Abbasi, J. W. Craft Jr, D. S. Maxwell, C. Patel, I.V. Stupin, D. Bakthavatsalam, R. V. Market, J. T. Willerson, R. A. F. Dixon, P. Vanderslice, and A. V. Annapragada: Sci. Rep. 8 (2018) 3733. https://doi. org/10.1038/s41598-018-21893-X

64 K. Affram, T. Smith, S. Helsper, J. T. Rosenberg, B. Han, J. Trevino, and E. Agyare: Cancer Nanotechnol. 11 (2020) 5. https://doi.org/10.1186/s12645-020-00061-9

65 Y. Li, Y. Du, X. Liang, T. Sun, H. Xue, J. Tian, and Z. Jin: Nanoscale 10 (2018) 16738. https://doi.org/10.1039/ c8nr05803b

66 P. Šimečková, F. Hubatka, J. Kotouček, P. Turánek Knötigová, J. Mašek, J. Slavík, O. Kováč, J. Neča, P. Kulich, D. Hrebík, J. Stráská, K. Pěnčíková, J. Procházková, P. Diviš, S. Macaulay, R. Mikulík, M. Raška, M. Machala, and J. Turánek: Sci. Rep. 10 (2020) 4780. https://doi.org/10.1038/s41598-020-60284-Z

67 E. Stride and M. Edirisinghe: Soft Matter 4 (2008), 2350. https://doi.org/10.1039/b809517p

68 R. G. Barr, P. Huang, Y. Luo, X. Xie, R. Zheng, K. Yan, X. Jing, Y. Luo, H. Xu, X. Fei, and J. Min Lee: Abdom. Radiol. 45 (2020) 3779. https://doi.org/10.1007/s00261-020-02573-9

69 K. W. Ferrara, M. A. Borden, and H. Zhang: Acc. Chem. Res. 42 (2009) 881. https://doi.org/10.1021/ar8002442 
70 P. S. Epstein and M. S. Plesset: J. Chem. Phys. 18 (2004) 1505. https://doi.org/10.1063/1.1747520

71 S. Sirsi and M. Borden: Bubble Sci. Eng. Technol. 1 (2009) 3. https://doi.org/10.1179/175889709x446507

72 T. Zhou, W. Cai, H. Yang, H. Zhang, M. Hao, L. Yuan, J. Liu, L. Zhang, Y. Yang, X. Liu, J. Deng, P. Zhao, G. Yang, and Y. Duan: J. Control. Release 276 (2018) 113. https://doi.org/10.1016/j.jconrel.2018.03.008

73 Y. Negishi, N. Hamano, Y. Tsunoda, Y. Oda, B. Choijamts, Y. Endo-Takahashi, D. Omata, R. Suzuki, K. Maruyama, M. Nomizu, M. Emoto, and Y. Aramaki: Biomaterials 34 (2013) 501. https://doi.org/10.1016/j. biomaterials.2012.09.056

74 Y. Li, W. Huang, C. Li, and X. Huang: RSC Adv. 8 (2018) 33198. https://doi.org/10.1039/c8ra03193b

75 E. Huynh, B. Y. C. Leung, B. L. Helfield, M. Shakiba, J. A. Gandier, C. S. Jin, E. R. Master, B. C. Wilson, D. E. Goertz, and G. Zheng: Nat. Nanotechnol. 10 (2015) 325. https://doi.org/10.1038/nnano.2015.25

76 H. Kim, H. Lee, H. Moon, J. Kang, Y. Jang, D. Kim, J. Kim, E. Huynh, G. Zheng, H. Kim, and J. H. Chang: ACS Photonics 6 (2019) 2268. https://doi.org/10.1021/acsphotonics.9b00576

77 A. I. Jensen, G. W. Severin, A. E. Hansen, F. P. Fliedner, R. Eliasen, L. Parhamifar, A. Kjær, T. L. Andresen, and J. R. Henriksen: J. Control. Release 269 (2018) 100. https://doi.org/10.1016/j.jconrel.2017.11.006

78 S. J. Blocker, K. A. Douglas, L. A. Polin, H. Lee, B. S. Hendriks, E. Lalo, W. Chen, and A. F. Shields: Theranostics 7 (2017) 4229. https://doi.org/10.7150/thno.21688

79 T. Suzuki, M. Ichihara, K. Hyodo, E. Yamamoto, T. Ishida, H. Kiwada, H. Ishihara, and H. Kikuchi: Int. J. Pharm. 436 (2012) 636. https://doi.org/10.1016/j.ijpharm.2012.07.049

80 Y. Hashimoto, T. Shimizu, Y. Mima, A. S. Abu Lila, T. Ishida, and H. Kiwada: Toxicol. Appl. Pharmacol. 277 (2014) 30. https://doi.org/10.1016/j.taap.2014.03.002

81 Y. Ma, Q. Yang, L. Wang, X. Zhou, Y. Zhao, and Y. Deng: Eur. J. Pharm. Sci. 45 (2012) 539. https://doi. org/10.1016/j.ejps.2011.11.014

82 T. Shimizu, A. S. Abu Lila, R. Fujita, M. Awata, M. Kawanishi, Y. Hashimoto, K. Okuhira, Y. Ishima, and T. Ishida: Eur. J. Pharm. Biopharm. 127 (2018) 142. https://doi.org/10.1016/j.ejpb.2018.02.019

83 B. Børresen, J. R. Henriksen, G. Clergeaud, J. S. Jørgensen, F. Melander, D. R. Elema, J. Szebeni, S. A. Engelholm, A. T. Kristensen, A. Kjær, T. L. Andresen, and A. E. Hansen: ACS Nano 12 (2018) 11386. https:// doi.org/10.1021/acsnano.8b06266

84 M. Mohamed, E. Alaaeldin, A. Hussein, and H. A. Sarhan: J. Adv. Biomed. Pharm. Sci. 3 (2020) 80. https://doi. org/10.21608/jabps.2020.22937.1068

85 S. Miyata, S. Kawabata, R. Hiramatsu, A. Doi, N. Ikeda, T. Yamashita, T. Kuroiwa, S. Kasaoka, K. Maruyama, and S. I. Miyatake: Neurosurgery 68 (2011) 1380. https://doi.org/10.1227/neu.0b013e31820b52aa

86 B. Siddhardha and P. Parasuraman: Nanomaterials for Drug Delivery and Therapy, A. M. Grumezescu, Eds. (Elsevier, Amsterdam, 2019) 1st ed., Chap. 3.

87 Y. Li, F. Jia, X. Deng, X. Wang, J. Lu, L. Shao, X. Cui, Z. Pan, and Y. Wu: Biomater. Sci. 8 (2020) 7132. https:// doi.org/10.1039/d0bm01579b

88 U. Ruman, S. Fakurazi, M. J. Masarudin, and M. Z. Hussein: Int. J. Nanomed. 15 (2020) 1437. https://doi. org/10.2147/ijn.s236927

89 H. Xiong, S. Liu, T. Wei, Q. Cheng, and D. J. Siegwart: J. Control. Release 325 (2020) 198. https://doi. org/10.1016/j.jconrel.2020.06.030

90 R. Tenchov, R. Bird, A. E. Curtze, and Q. Zhou: ACS Nano 15 (2021) 16982. https://doi.org/10.1021/ acsnano.1c04996 